International Journal of Geography and Geology

2014 Vol. 3, No. 2, pp. 30-44

$\operatorname{ISSN}(e): 2305-7041$

$\operatorname{ISSN}(p): 2306-9872$

DOI: 10.18488/journal.10/2014.3.2/10.2.30.44

(C) 2014. Conscientia Beam. All Rights Reserved.

CrossMark

\title{
TECTOMAGMATIC ORIGIN OF THE ZAHEDAN BATHOLITHS - SOUTH EAST IRAN (RELING ON INTERGRATED OUTCROP STUDY OF THE PETROLOGY OF HIGH MASS IN LOOCHAN, SOUTHWEST ZAHEDAN)
}

\section{Behrooz Sahebzadeh ${ }^{1}$}

${ }^{\prime}$ Department of Geosciences, Farhangian University, Shahhid Motahhari Campus, Zahedan, Iran

\begin{abstract}
Zahedan batholiths, the largest intrusive igneous mass in Sistan Suture zone, in Southeast of Iran during the Eocene - Oligocene is formed in this zone. The mass of igneous outcrops in a narrow mass with scattered outcrops Larger populations with continuous advice, The Afghan Block of East and West Blocks of Lout outcrop at the surface, Granitoid batholiths magma intrusion in the petrographical Zahedan region specific and that the mass of Tectomagmatic origin of calc-alkaline and per aluminous igneous intrusion that is Melting of continental sedimentary rocks in the shallow crust Lateral movement of the compression zone includes the land area is under construction .
\end{abstract}

Keywords: Southeast of Iran, Sistan Suture zone, Zahedan igneous intrusions, Loochan batholiths, Tectomagmatic origin, Melting of the continental crust, Petrological diagrams.

Received: 30 November 2013/ Revised: 23 January 2014/ Accepted: 28 January 2014/ Published: 3 February 2014

\section{INTRODUCTION}

Mass of plutonic igneous Zahedan in the range of longitude $60^{\circ}$ and $61^{\circ} 40^{\prime}$ eastern longitude and latitude $29^{\circ}$ to $29^{\circ} 30^{\prime}$ North, with an area $75 \mathrm{OKm}^{2}$ and the average height of $2200 \mathrm{~m}$ above sea level In South East Iran, near Pakistan and Afghanistan. (Figure 1).

Figure-1. Geographical location of Zahedan Batholiths in South East Iran

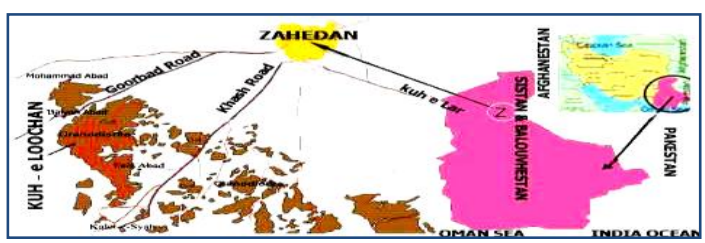


The mass of the batholiths, the South West (Goorband) to South East (Mirjaveh) Zahedan city, near the border with Pakistan, low dispersion and high Loochan with outcrops extensively on the surface appears (Figure 2).

Figure-2. Location of Sistan- Suture Zone - South- East Iran

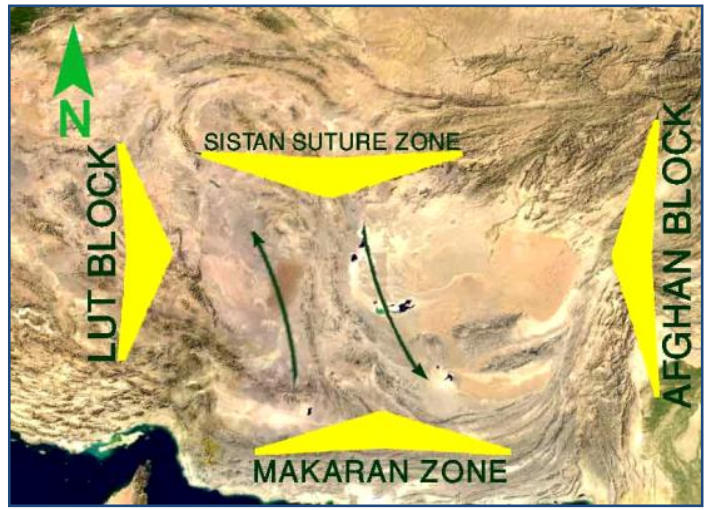

Intrusive igneous mass acme in Zahedan, the igneous peaks with an altitude of about $2565 \mathrm{~m}$ above sea level is Loochan. Loochan lowest points mainly in southern regions, Have an altitude of about $1700 \mathrm{~m}$ above sea level is. Loochan peak with $2565 \mathrm{~m}$ and Morgan Peak with an altitude of around $2403 \mathrm{~m}$, located approximately parts of the central mass of the batholiths. The largest mass of igneous outcrop, Loochan an integrated part of the peak is located in an area of $150 \mathrm{Km}^{2}$.

Access roads to the north of the batholiths Loochan, Goorband rural paved road length of about $20 \mathrm{~km}$ (distance to fault village Goorband 3 at the end of the valley of the same name) is Siyadak to the village. East side of road access to the village Gharib Abad - e - Loochan batholiths and eastern highlands Loochan and Morgan, about $20 \mathrm{~km}$.

\section{ACCESS ROADS}

Batholiths Loochan access route from the south and southwest, Approximately 10 kilometers of paved road in grade one - Zahedan, Khash Plus, about $20 \mathrm{~km}$ from Faizabad Rural asphalted road Loocho And South are Rahmat Abad. Access to the western side of the batholiths Loochan about $30 \mathrm{~km}$ asphalt road in Zahedan - Kash and about 12miles of paved roads and 10kilometers of rural roads and Qatar khanjak - Rural Ebrahim Abad. In this area, adjacent to the batholiths contact and regional metamorphic schist's Loochan with igneous - metamorphic rocks older batholiths metamorphic visible. Specificities of climate on geographical limit mass of igneous intrusions Zahedan, hot and dry (Fig.3) With drastic changes in daily and annual temperatures are, of climatology in the border desert climate - semi- desert is located (Ebrahimzadeh, 2007). 
Figure-3. Desert climate - semi-desert in the batholiths Loochan

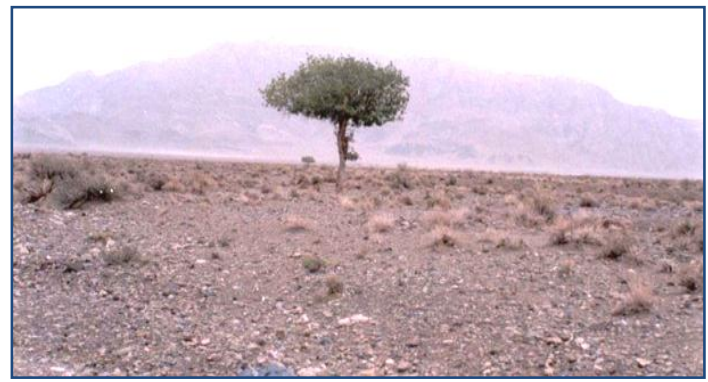

\section{REGIONAL CLIMATE}

Specificities of the regional climate, plays a major role in the degradation and erosion of rocks and thus make certain geomorphologic structure of the play. Low humidity, high temperatures and a wide range of temperature changes, especially during the day and seasons as the most important form of degradation phenomena Temperature cleavage and the water content in the cleavage of water and ice cleavage phenomenon has led to the degradation rocks occurred mainly in physical form, Performance of physical weathering chemical weathering in the region is evident.

\section{HISTORYOFGEOLOGY}

Studies on the geological history of the South East and intrusive igneous mass Zahedan published field studies (Berberian and King, 1981), Camps and Griffis (1982), Tirrul et al. (1983) and... Begins. The dimensions of the batholiths varies between stocks and dykes. The extent of intrusive igneous mass of Zahedan Garagheh mountain in the mountains northwest of Zahedan Bug mountain- Mirjaveh near the border with Pakistan and Iran, about 200 kilometers (Boomeri and Lashkaripour, 2003). Area about $250 \mathrm{~km}$ long and extends longitudinally Saravan are. Based on measurements of argon and potassium Zahedan examples Granitoid Camps and Griffis (1982) to determine the age of rocks formed about 32 million years for the time being.

Lithology in Zahedan batholiths consists of five original rock masses, dikes parallel or nearly parallel, Various xenoliths, of quartz veins and pegmatite's (Boomeri and Lashkaripour, 2003) has been divided. The final phase of magmatic activity in the southeastern Iranian city of Zahedan in Tectonic pegmatite's batholiths can be seen.

Zahedan batholiths in the central region of Sistan-Suture Zone (Tirrul et al., 1983), which is also called Sistan region of the joints, the two blocks broad and strong, but rotary motion Lout in West and the Afghan East as a part of outcrop of narrow (Berberian and King, 1981),It forms the tectonic vents in the Lout Block, the West Block Helmand (Afghanistan) in the East know (Berberian and King, 1981). Tectonic activity in the area at hat are affected by numerous faults, not the fault of Zahedan- Zahedan fault Nosrat Abad in the West and in the East(Fig.4) are (Camps and Griffis, 1982). 
Figure-4. The main fault zone of eastern Iran

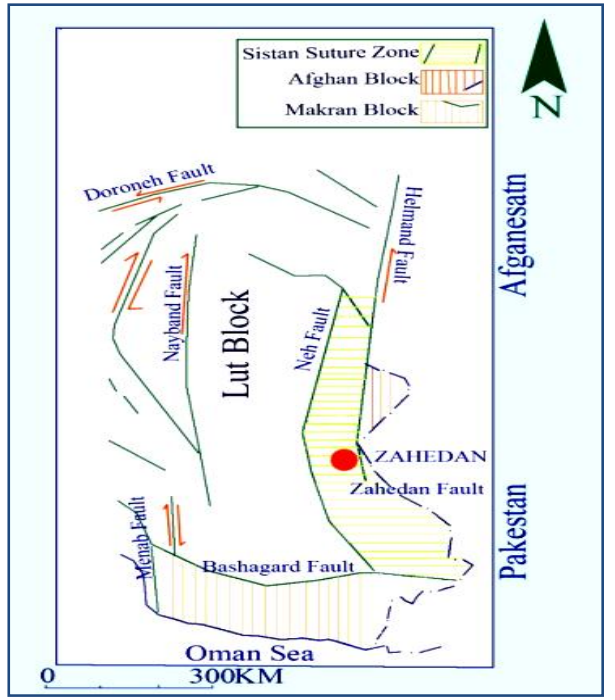

\section{PETROLOGY OF MAGMATIC SERIES}

Petrological diagrams for the most popular series of acidic magmatic plutonic igneous rocks, Changes in chemical composition of the alkali- silica diagram of the Changes in the chemical composition of the alkali-silica diagram of percentage changes Chemical analysis of rock samples taken from outcrops of igneous body is acidic inside(Table 1). Using this diagram (Fig. 6), alkaline and sub-alkaline magmatic series are separated.

Table-1. Chemical analysis of samples of intrusive igneous mass Zahedan

\begin{tabular}{lccccccc}
\hline Sample NO. & SiO2 & FeO+ Fe2O3 & Al2O3 & Mg O & Ca O & Na2O & K2O \\
\hline L1 & 60.73 & 2.82 & 21.36 & 5.42 & 4.97 & 3.45 & 2.25 \\
\hline L2 & 68.23 & 2.33 & 16.51 & 6.65 & 3.02 & 2.98 & 2.25 \\
\hline L3 & 59.78 & 2.61 & 17.87 & 9.40 & 5.90 & 3.29 & 2.17 \\
\hline L4 & 65.10 & 2.42 & 17.28 & 6.79 & 4.05 & 3.02 & 2.34 \\
\hline Z1 & 62.88 & 4.68 & 17.42 & 1.26 & 3.68 & 3.33 & 3.41 \\
\hline Z2 & 68.3 & 3.12 & 14.50 & 1.83 & 2.11 & 2.96 & 4.17 \\
\hline Z3 & 68.26 & 2.96 & 15.49 & 2.25 & 2.56 & 3.23 & 4.07 \\
\hline Z4 & 66.6 & 3.37 & 15.20 & 2.46 & 3.32 & 2.75 & 3.32 \\
\hline Z5 & 63.0 & 5.11 & 16.20 & 3.89 & 2.94 & 1.93 & 3.92 \\
\hline Z6 & 78.8 & 0.92 & 10.00 & 0.23 & 1.26 & 2.84 & 5.58 \\
\hline Z7 & 77.5 & 1.47 & 13.30 & 0.90 & 1.21 & 2.55 & 5.48 \\
\hline D1 & 70.0 & 2.70 & 15.8 & 1.02 & 3.03 & 4.41 & 2.66 \\
\hline D2 & 58.1 & 5.20 & 15.6 & 3.64 & 5.60 & 3.70 & 2.91 \\
\hline K1 & 67.1 & 3.59 & 15.79 & 1.27 & 3.46 & 3.79 & 2.85 \\
\hline K2 & 68.2 & 3.16 & 16.10 & 1.75 & 3.44 & 4.20 & 1.95 \\
\hline K3 & 56.9 & 6.16 & 24.30 & 1.96 & 3.12 & 3.48 & 2.45 \\
\hline K4 & 61.4 & 4.78 & 18.90 & 1.76 & 3.36 & 3.68 & 2.23 \\
\hline K5 & 67.5 & 3.58 & 15.50 & 1.37 & 3.46 & 3.80 & 3.36 \\
\hline K6 & 54.8 & 6.52 & 26.20 & 2.02 & 3.01 & 3.12 & 2.86 \\
\hline K7 & 59.9 & 5.31 & 21.70 & 1.68 & 3.18 & 3.29 & 2.34 \\
\hline
\end{tabular}


1: Sample NO. L-1/L-4: Analysis of the LOOCHAN Granitoid. (Analyzer: Tiran Sotoon Co.)

2: Sample NO. Z-1/Z-6: Analysis of the ZAHEDAN Granitoid. (Analyzer: Ab and Khak CO.)

3: Sample NO. D-1/D-2: Analysis of the DYKE ZAHEDAN Granitoid. (Analyzer: Ab and Khak CO.)

4: Sample NO. K-1/K-7: Analysis of the KATKHANJAK Granitoid. (Analyzer: Kimia Sang CO.)

Figure-5. Separation of alkaline and sub-alkaline magmatic series of other (Boomeri and Lashkaripour, 2003), (The continuous line) and (Boomeri and Lashkaripour, 2003) (Discontinuous line)

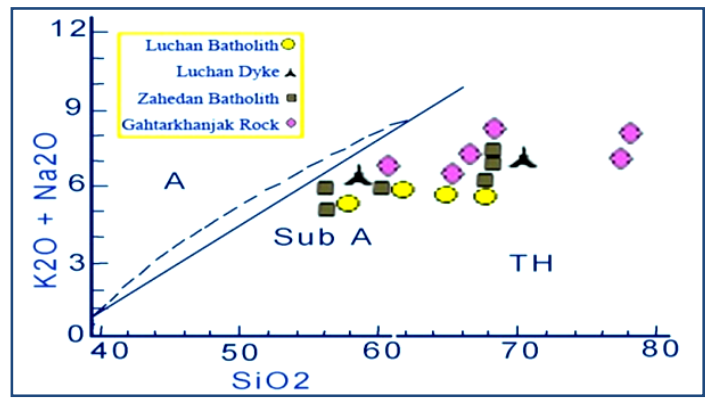

This diagram (Fig. 5) is based on the results of the chemical analysis of the mass of plutonic igneous rocks Zahedan (Tables 1-L, 1-Z, 1-D and 1-K) has been prepared, Suggests that the formation of these tumors ranges from sub - alkaline magmatic series of fact.

Diagram, who found fame TAS diagram, consisting of a series of magmatic zone Fooiditik (Boomeri and Lashkaripour, 2003), alkaline magmatic series of regional, trans- alkaline magmatic series of regional, district and subalkaline magma series, is a series of silicon magma.

Figure-6. Diagram TAS (Boomeri and Lashkaripour, 2003)and location of the studied rocks

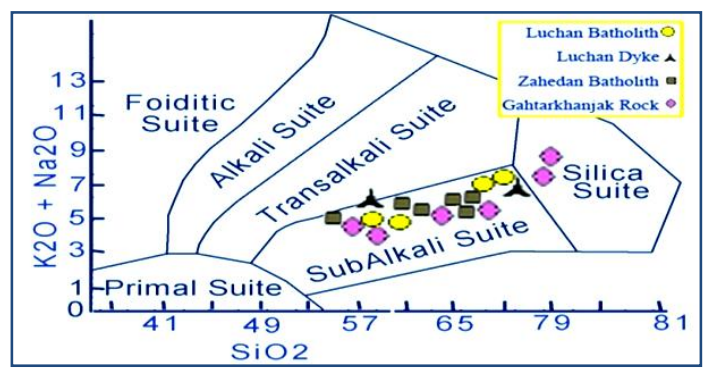

Diagram TAS (Fig. 6) provides for the interpretation of the mass of plutonic igneous magma series Zahedan that Loochan batholiths rocks outcrop within the study area, are placed within the sub-alkaline magma series.

In Petrological diagram Kuno (1968) developed areas of the region1 (range alkaline magmatic series), Region2 (Calc-Alkaline magma series range) and region3 (Magmatic series range tholeitiy) respectively. 
Figure-7. Diagram of Alkali - Silica Kuno (1968) and the position of the igneous rocks

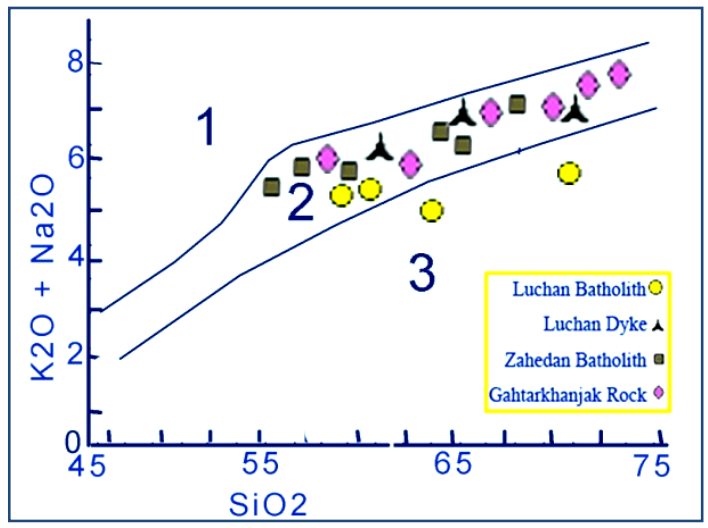

Diagram Alkali - Silica (Boomeri and Lashkaripour, 2003) prepared for the magmatic series in Zahedan batholiths (Fig. 7), indicating that the Granitoid are placed within the alkaline magmatic series.

The diagram for the separation of magmatic Calc-alkaline series, Alkaline and Per Alkaline used(Boomeri and Lashkaripour, 2003).

Figure- 8. Diagram Wright (1969) and the position of the igneous rocks

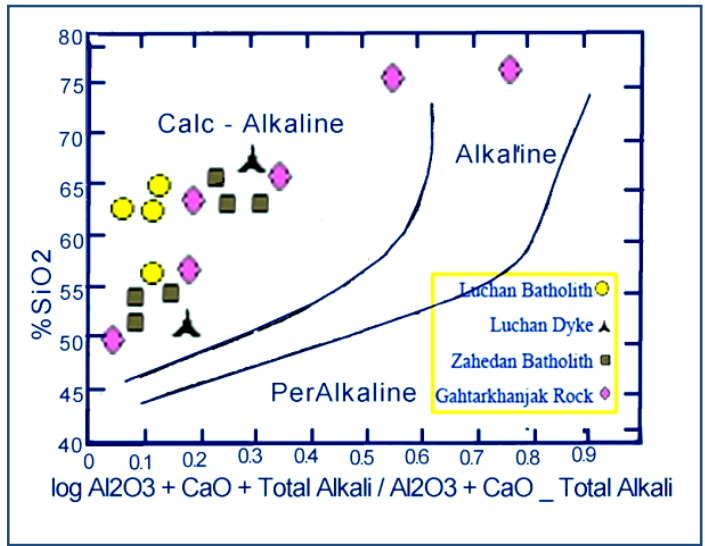

According to this diagram (Fig. 8) Granitoid of the batholiths in Zahedan integrated within large outcrops and high Loochan, Alkaline magmatic series are placed within. Using diagram parameters of quartz - plagioclase feldspar and alkaline intrusive rocks from chemical analyzes of volcanic areas (Berberian and King, 1981), ranges and different sets of magmatic plutonic igneous areas are separated. 
Figure-9.Chart Position QAP modal igneous rocks in the study area.

ANA (alkaline sodium), AIK (SP aluminum arrow), SAM (subalkaline monzonite), CAG (alkaline granodiorite), CAT (tonalite - tronjomite alkaline).

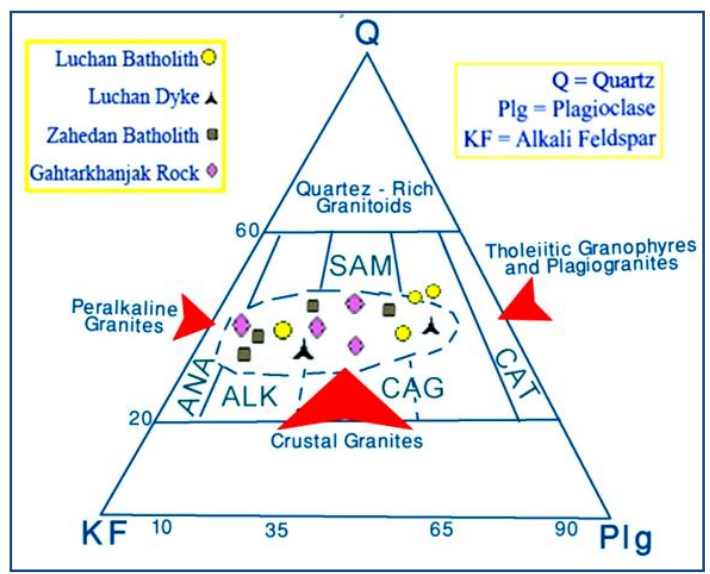

According to this diagram (Figure 9), the igneous rocks granite and granodiorite batholiths in the Zahedan area and Calc-alkaline series has been the fit chart Granitoid show up at Zahedan, Are shell -type granites.

These findings with the results of field studies from other researchers that show evidence suggests crustal origin granites mass of igneous intrusions Zahedan (Tirrul et al., 1983), (Sadeghian and Valizadeh, 2007), (Sadeghian and Valizadeh, 2007), (Sadeghian and Valizadeh, 2007) is consistent.

Triangular diagram using AFM (Boomeri and Lashkaripour, 2003) Determination of internal igneous magma segregation and Tholeitiy alkaline magmatic series is done.

Figure-10. AFM ternary diagram position within the batholiths intrusive igneous rocks Loochan

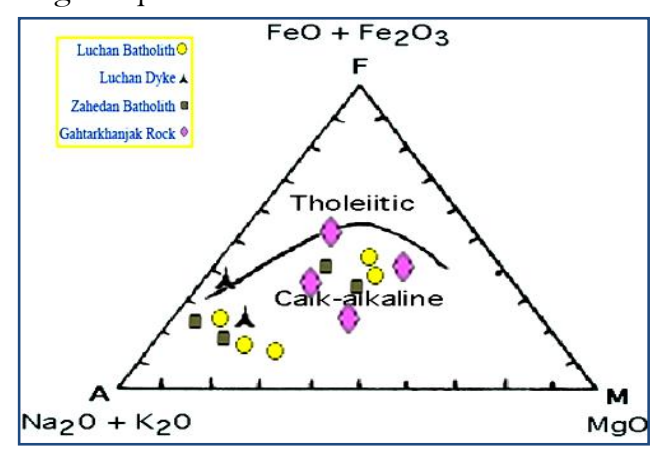

The ternary diagram of the AFM (Fig. 11) consists of igneous rocks in the geographic area within the Calc-alkaline batholiths are Zahedan. Ternary diagram of $\mathrm{Al} 2 \mathrm{O} 3 / \mathrm{FeO} / \mathrm{MgO}$ ternary diagram similar AFM (Boomeri and Lashkaripour, 2003) and separated into two series alkaline magmatic trustee determines. 
Figure-1 1.Diagram of the ternary $\mathrm{Al}_{2} \mathrm{O} 3 / \mathrm{FeO} / \mathrm{MgO}$ and location of the studied rocks

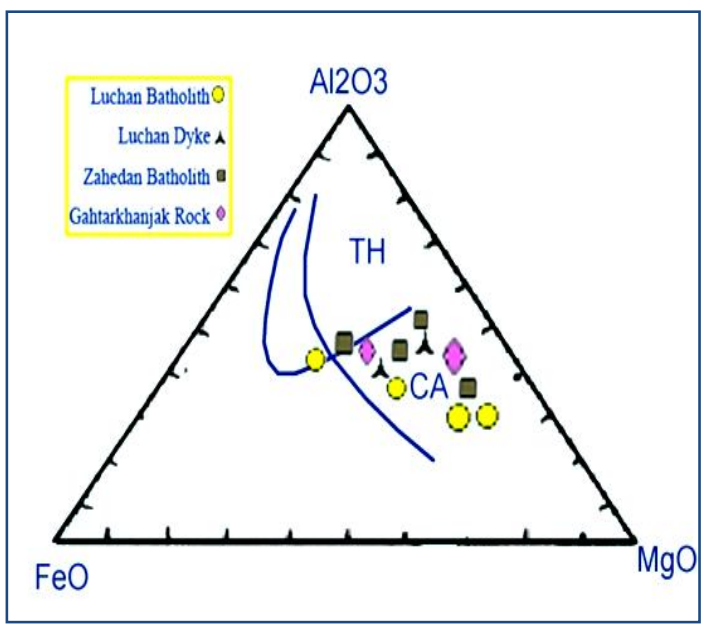

The ternary diagram of $\mathrm{Al} 2 \mathrm{O} 3 / \mathrm{FeO} / \mathrm{MgO}$ (Fig. 12) intrusive igneous rocks of calcalkaline magma within the study area are placed.

Ternary diagram for the separation of the two series and calc-alkaline magma of another puppies ET presented (Boomeri and Lashkaripour, 2003).

Figure-12. Position FNM ternary diagram of the studied rocks the numbers range 1, range and range number 2 ET Cubs series magmas, the magmas of the calc-alkaline series of the show

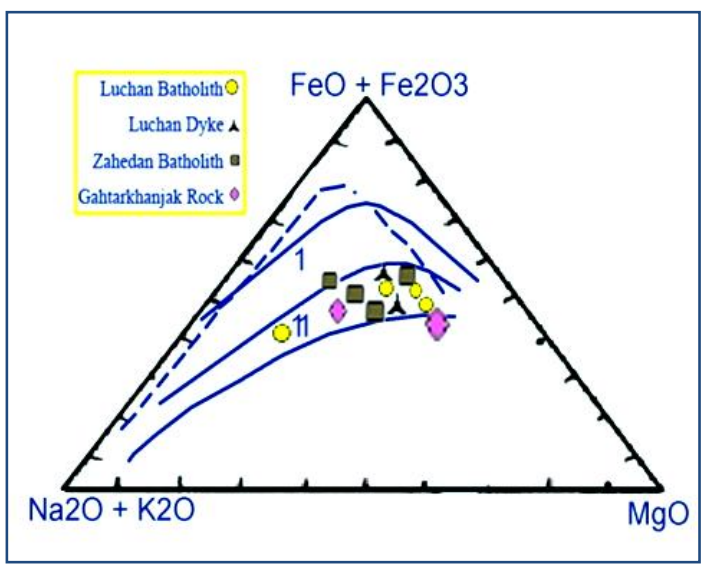

Detailed diagram son Kuno (1968) (Fig. 12) Zahedan intrusive igneous mass, particularly in the area Loochan batholiths, lies within the calc-alkaline magma series. Field studies and summarized the results also show that the nature of the igneous intrusive mass of granite in Zahedan, is alkaline (Sadeghian and Valizadeh, 2007). 


\section{TECTONIC SETTING}

Experimental work (Clinic, 1972), (Clinic, 1972), (Berberian and King, 1981).shows that the water-saturated conditions and at low pressures in the crust between 2 to 4 kilo bars pressure, partial melting of sedimentary rocks Such as shale and greywacke, Granitic melt is obtained . The experimental work (Clinic, 1972) showed that a molten granite or granodiorite melt plate of scale can be achieved. The following evidence suggests that the origin of granites are shallow continental (MoinVazeri and Ahmadi, 2002):

- Adoption of the acid and the formation of large igneous body mass batholiths solid and rigid shell is problematic unless they are the result of partial melting of continental crust to know.

- Many different enclaves, especially enclaves of sedimentary and metamorphic, that some are even little changes cannot be seen (Fig. 13).

Figure-13.Example of Sedimentary xenoliths in the Loochan

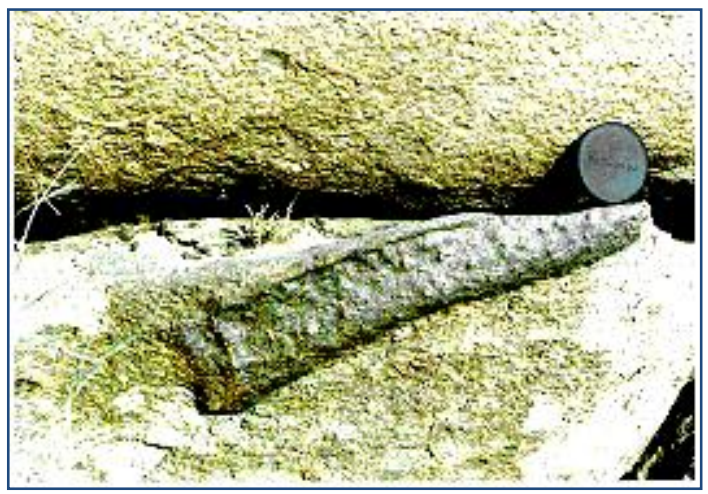

- The transformation of low- grade metamorphic rocks indicate formation under low temperature and low pressure, the lower the melting of deep continental crust, is (Fig. 14).

Figure-14.Batholiths near Zahedan (brighter part) metamorphic rocks from the melt (darker parts)

(Photo from the southern part Loochan - Takhtak - e- Ghatarkhanjak is harvested.)

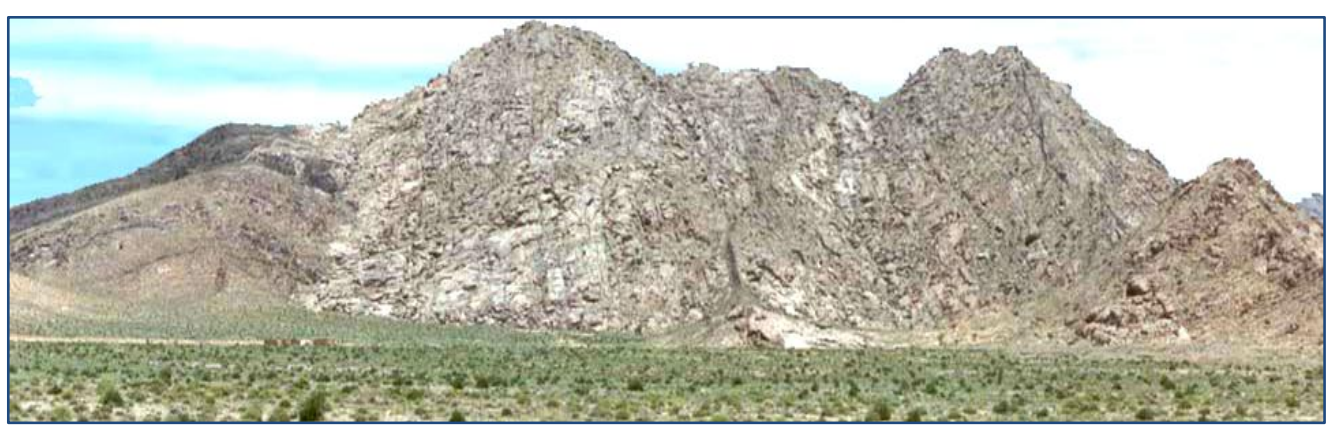

The Granitoid masses and chemical analysis of major element sand trace elements, diagrams and charts to fit experimental the role of tectonic origin, two groups. Orogenic and non-Orogenic 
Granitoid of Granitoid are classified. Terms of Orogenic Granitoid AL2O3amountsofnonorogenicgranitoidarericher there are Diaper batholiths the calc-alkaline batholiths and domes are seen to be of materials that are rich in alkali. In contrast, non-Orogenic Granitoid are associated with alkaline complexes (Sadeghian and Valizadeh, 2007).

To determine the origin of rocks and tectonic Granitoid masses based on the main elements of the chemical analysis of samples taken from outcrops of plutonic igneous masses have presented a model. They are related to the basic elements, the type of Orogenic Granitoid are divided as follows (MoinVazeri and Ahmadi, 2002):

1 -Type of IAG, the type (Island Arc Granitoid) which includes a granite island arc subduction of an oceanic plate under another oceanic plate are formed in island arcs.

2 -Type CAG, continental arc Granitoid (Continental Arc Granitoid) the subduction of one plate of a typical subduction of the oceanic plate under a continental heavy to lighter continental parts are inside .

3 -Type CCCa, continental collision Granitoid (Continental) during the collision and the collision of two continental plates - continental form.

4- -Type POG, Granitoid are in the final stages of an Orogenic at the end of deformations in the continental crust are formed.

The diagram $\mathrm{K} 2 \mathrm{O} / \mathrm{SiO} 2$ to separate the ocean plagiogranite (Op) Series Granitoid used (MoinVazeri and Ahmadi, 2002).

Figure-15.Position of the rocks in the study are a variation wt $\% \mathrm{~K} 2 \mathrm{O}$ Changes compared towt $\% \mathrm{SiO} 2$

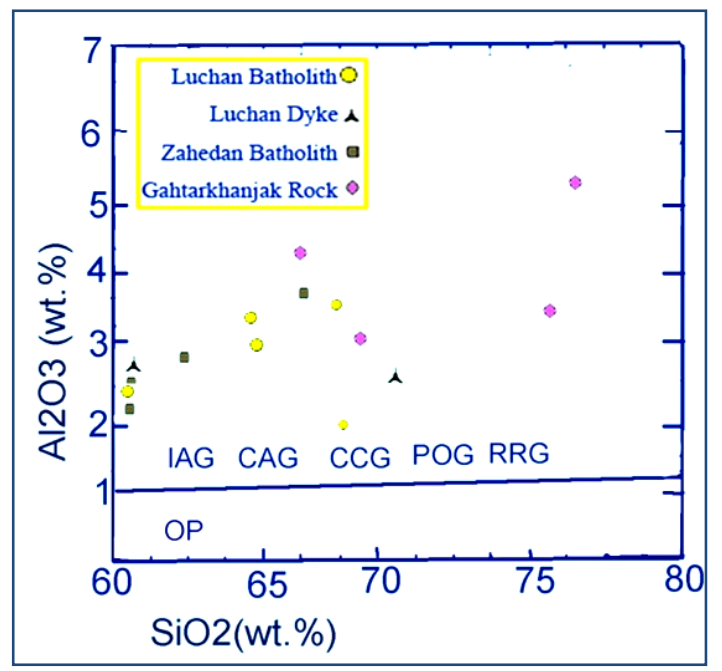

According to the diagram (Fig. 15), outside the range of Granitoid are plagiogranite oceans.

The diagram wt. \% $\mathrm{Al} 2 \mathrm{O} 3 /$ wt. \% $\mathrm{SiO} 2$ Granitoid of Group I (type of IAG, Ggg) Granitoid of Group II (types CEUG, IRRG) and Group III (type POG) have been separated. 
Figure-16. Position of the rocks in the study are a variation wt. \%Al2O 3 Changes compared to wt. $\% \mathrm{SiO} 2$

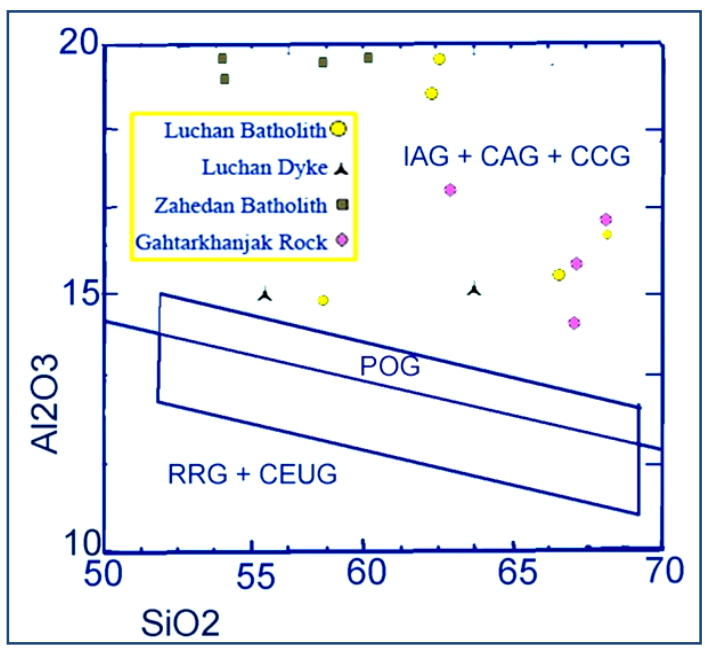

The above diagram (Fig. 16) shows that the Granitoid Zahedan Group I (Types TAG, GAH and $\mathrm{CCG}$ ) is placed.

Diagram wt. \% A / A + K vs. wt. \% A / N + c + k (MoinVazeri and Ahmadi, 2002), (MoinVazeri and Ahmadi, 2002), which represents the change in mole percent Cat ion and $\mathrm{h}$ is the index of Shand (Shand's index) (MoinVazeri and Ahmadi, 2002) is known for the separation of continental collision granitoid (CCG) from two other types of granite Group I (TAG, CAG) is used.

Figure-17.Position of the rocks in the study area Shand index chart

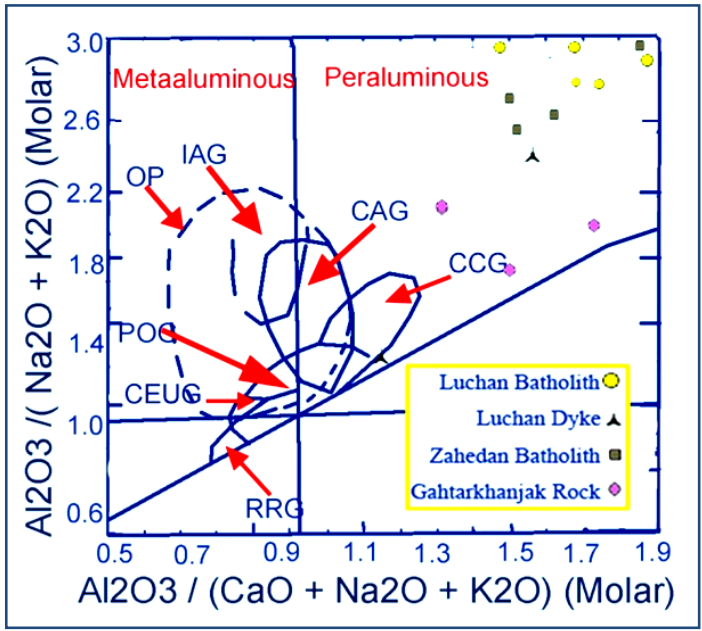

The diagram (Fig.17) shows examples of intrusive igneous mass, geographic range, and especially in Zahedan Loochan batholiths, Located within the peraluminous, Granites formed in 
this region, Granite type of aluminum-rich TAG, CCG that the continental plates are colliding with, is.

Per aluminous granites of the batholiths is the nature of evidence suggests Zahedan (Sadeghian and Valizadeh, 2007). Zargoly granites in Zahedan, the types are rich in alumina (Boomeri and Lashkaripour, 2003).

Diagram of wt. $\% \mathrm{SiO} 2$ versus wt. $\% \mathrm{FeO} / \mathrm{FeO}+\mathrm{Mg} \mathrm{O}$ for the breakdown of granite types I, II, III are used.

Figure-18. Graph changes wt. \% oxide into the silica rocks Position

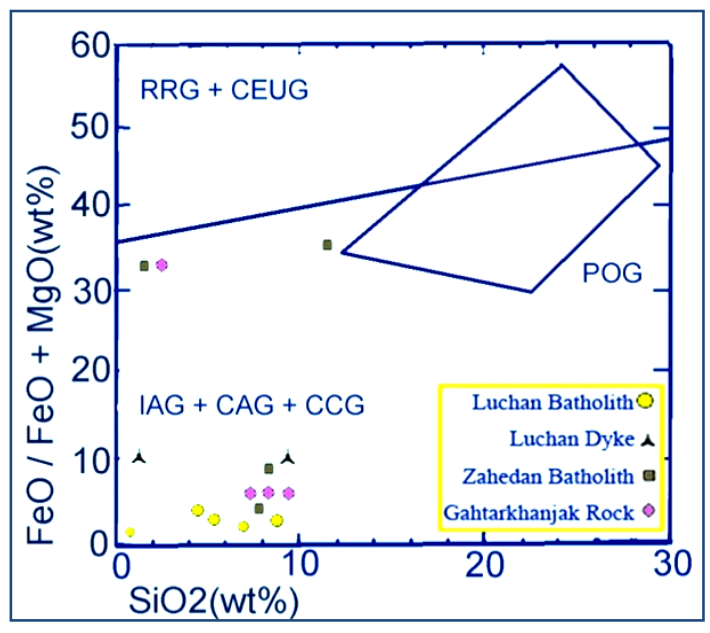

The diagram (Fig. 18) shows that within the studied Granitoid of Group I and type granites TAG, CAG, CCG are placed. Based on petrography studies, I type granites can be introduced Zahedan (Boomeri and Lashkaripour, 2003) and (Boomeri and Lashkaripour, 2003).

Diagram of the wt. \%FeO / MgO (Sadeghian and Valizadeh, 2007), and Maniar and Piccoli (1989) for further separation of the three groups of rocks are used.

Figure-19.Graph wt. \% $\mathrm{FeO}$ change of position versus wt. \% $\mathrm{MgO}$ variations of Granitoid south of Iran

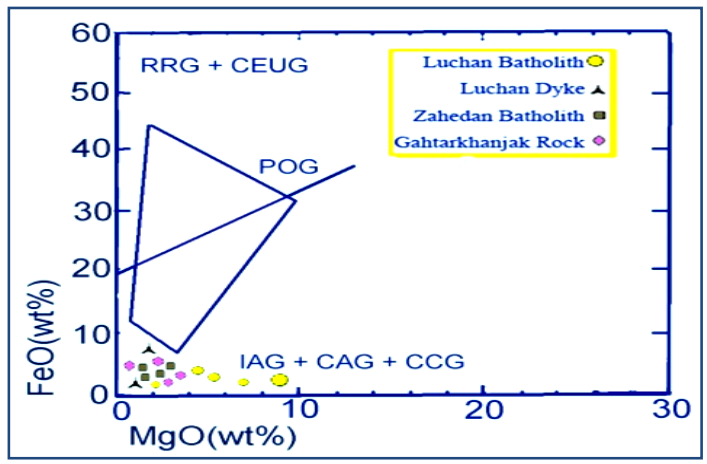

The diagram (Fig. 19) also shows that the studied Granitoid are placed in group I. 
wt. \% $\mathrm{CaO}$ variation diagram of the variation of wt.\% $\mathrm{FeO}+\mathrm{MgO}$ (MoinVazeri and Ahmadi, 2002) for the separation of Granitoid from Group I, II and III are used.

Figure-20. The chart changes in wt. $\% \mathrm{FeO}+\mathrm{MgO}$ vis-à-vis wt. $\% \mathrm{CaO}$ and position changes the rock

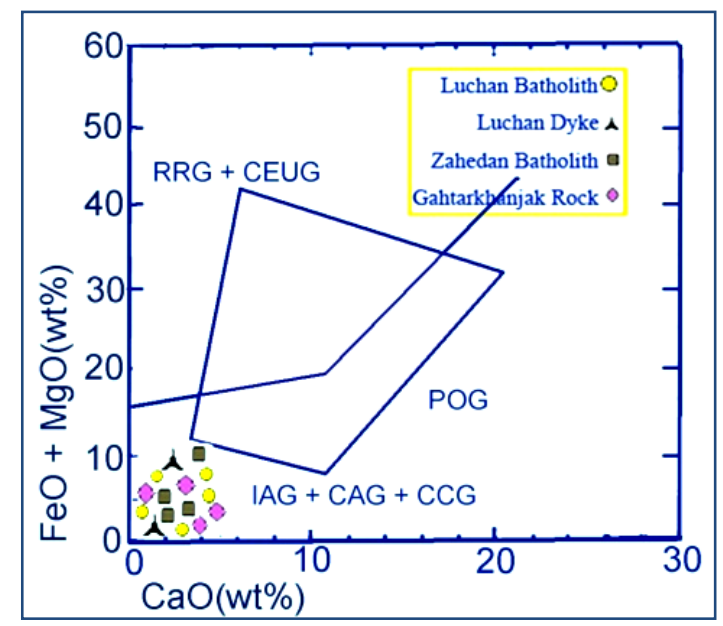

The diagram (Fig. 20) also confirms that the Group I Granitoid are located within the study area. I -type Granitoid intrusive igneous mass belongs to Zahedan (Boomeri et al., 2004), (Sadeghian and Valizadeh, 2007). Lakhshak mass of granodiorite, 10 kilometers northeast of the city of Zahedan in great abundance The $\mathrm{P}_{2} \mathrm{O} 5$ and $\mathrm{SiO}_{2}$, similar to I -type granites (Sadeghian and Valizadeh, 2007).

The last step for the separation and determination of Granitoid Non-Orogenic RRG and CEUG types of chart weight wt.\% $\mathrm{TiO} 2$ versus wt. \% $\mathrm{SiO} 2$ (dig. 21), was used. This chart shows the range CEUG are Zahedan granites and granite -type continental onshore are creating.

Figure-2 1. Graph of changes in the status of Granitoid wt. \% TiO2 vis-à-vis Changes wt. \% $\mathrm{SiO} 2$

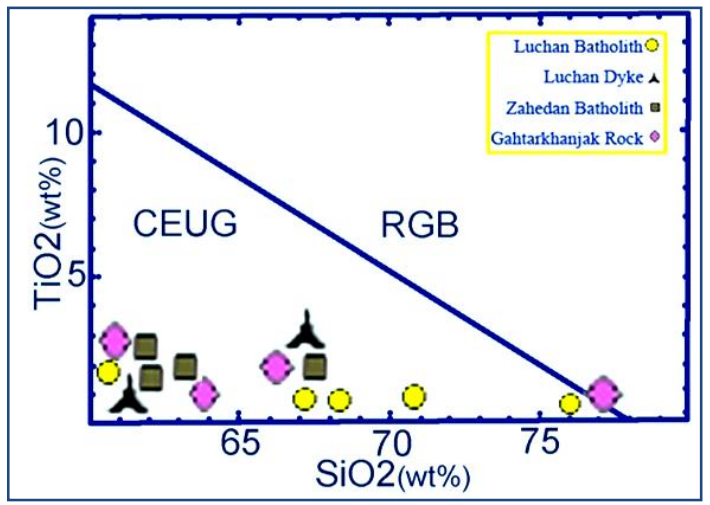

Tectonic setting of Granitoid based on the major, minor and rare earth similar position tectonic granites formed in continental margin located (Boomeri et al., 2004), a continental arc 
Granitoid and pre- treatment of the are treated as Orogenic granites are considered part of the (Sadeghian and Valizadeh, 2007). Lakhshak mass of granodiorite in the region, the northern part of the mass of intrusive igneous Zahedan, the amount of $\mathrm{TiO} 2$ in the rocks of the continental margin in the range of values are granite $\mathrm{TiO}_{2}$ (Sadeghian and Valizadeh, 2007). Tectonic setting discrimination diagrams, the position of the volcanic arc granites (VGA) for the continental margins of intrusive igneous mass appears Zahedan idea (Sadeghian and Valizadeh, 2007). The Granitoid rocks of Orogenic Granitoid types are VGA and CAG (Sadeghian and Valizadeh, 2007). Apparently, during the Cretaceous, Two Lout and Afghan blocks Separated by an ocean and a continent have. Looking at the various movements of continental Eurasia, closing the ocean, causing the two blocks together is great. The result of this approach, the flisch sediments a0.15end oceanic crust thrust rocks of calc-alkaline magmatic in the Zahedan granitic rocks were formed (Boomeri et al., 2004).

\section{CONCLUSION}

Based on the results of chemical analysis of rock samples taken from Loochan batholiths, dikes and intrusive igneous rock mass Qatarkhanjak in Zahedan in varied and numerous diagrams Petrological alkali - silica and The diagram of TAS, Alkaline magmatic rocks within the series And the amount of alumina, The mass range was per aluminous, The Tecton-magmatic origin, Granitoid in southeastern Iran (Zahedan intrusive igneous masses, especially in large outcrops, integrated and high Loochan in the northern part of the mass ) of land and the creation of continental plates collide, Local compressive shear zones within the study area Nehbandan - Kash between the two blocks wide, robust, But a lot of tectonic movements in the West and in the East under the Afghans, The main factor in the formation of continental crust melting, magma ascent and intrusion of igneous intrusive mass in the region of Zahedan, The origin of Granitoid Zahedan, type I -type granites that have been affected by sodicmetasomatism is determined .

Funding: This study received no specific financial support.

Competing Interests: The author declares that there are no conflicts of interests regarding the publication of this paper.

\section{REFERENCES}

Berberian, M. and G.C. King, 1981. Towards a paleogeography and tectonic evolution of Iran. Canadian Journal of Earth-Sciences, Reviews, 18(2): 210-265.

Boomeri, M. and G.R. Lashkaripour, 2003. Granite of Zahedan, Southeastern Iran. European Geophysical Research Abstracts, 5: 04933.

Boomeri, M., G.R. Lashkaripour and M.N. Gorgich, 2004. Geochemistry and petrography of Zahedan granitic rocks, research project. Zahedan: Sistan and Baluchistan University. pp:187

Camps, V.E. and R.J. Griffis, 1982. Character, genesis and tectonic setting of igneous rocks in the Sistan suture zone, Eastern Iran, Lithos.15 September 1982, 15(3): 22 1-239. 
Klinic, I.A., 1972. Experimental study of partial melting of coastal rocks and formation of migmatite, congers. Repot 24th Session, Montreal2. pp: 109-113.

Ebrahimzadeh, E., 2007. Fundamentals of Iran South-East longitude. Zahedan: Printing, Publishing, Sistan and Baluchistan University. pp: 473.

Kuno, H., 1968. Differentiation of basaltic magma, In Hess, H. H. et Poldervaart, A. Edit, Basalts. New York: Interscience Pull. 2: 623- 688.

Maniar, P. and P.M. Piccoli, 1989. Tectonic discrimination of granitoid. Geological Society of America Bulletin, 101(5): 635-643. [Accessed May 1989].

MoinVazeri, H. and A. Ahmadi, 2002. Petrography and petrology of igneous rocks. Tehran: Printing, Publishing, Teacher Training University. pp: 539.

Sadeghian, M. and M.V. Valizadeh, 2007. Granitoid emplacement mechanism of Zahedan in light of the methodology AMS. Journal of Earth Sciences, Geological Survey of Title, (66): 134-159.

Tirrul, R., I.R. Bell, R. Griffis and V.E. Camps, 1983. The Sistan suture zone of Eastern Iran. Geological society of American. Bulletin; January 1983, 94(1): 134-150.

Wright, J.B., 1969. A simple alkalinity ratio and its application to questions of non-orogenic granite gneiss. Geol. Mag, 106: 370-384.

\section{BIBLIOGRAPHY}

Kord. M. and H. Ghasemi and m. Sadegheian, 2009. Petrology and geochemistry of granitoid dikes dark mass in Willow Springs, Zahedan, Ninth Symposium of Geological Society of Iran, Tarbiat Moallem University, Tehran. pp: 203.

Rezaei-e-Kahkhaei, M., 2006. Petrogenesis and tectonic position of the Lakhshak and dykes (Northwest of Zahedan), MS Thesis, Tehran University. pp: 180.

Shand, S. J., 1943, The Eruptive Rocks. Their Genesis, Composition, Classification, and Their Relation to Ore-Deposits with a Chapter on Meteorite, New York: John Wiley \& Sons. pp: 440.

Winkler, H. G. F., 1974. Pathogenesis of metamorphic rocks, (3 ${ }^{\text {rd }}$ end), Springer Verlag: Berlin, Heidelberg, New York. pp: 320. 